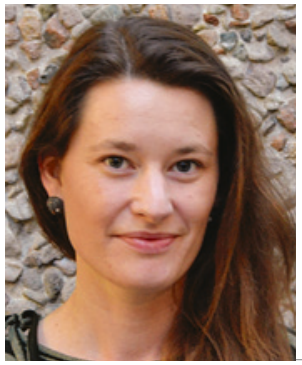

\section{Marte Rua}

Sosiolog og forsker ved Institutt for kriminologi og rettssosiologi Universitetet i Oslo

\title{
Ballen som ingen vil ta
}

Kriminologiprofessoren Nils

Christie fortalte meg nylig om en

lege han møtte på Ila fengsel på

1960-tallet. «Han var engstelig for

fengselsdirektørens reaksjoner,

følte seg underordnet denne. Slik

fikk jeg ideen til importmodellen.»

For å sikre helsepersonells uavhengighet innførte Norge denne modellen i norske fengsler i 1987 - som første land i verden. Legen skulle nå være ansatt av kommunen, og ifølge Helsedirektoratet være «fangers advokater i helsespørsmål». Importmodellen møtte begeistring internasjonalt, og er siden blitt innført i mange land.

Ideen er god - og viktig. Det sier også dagens fengselsleger. Fengselsmyndighetene skal først og fremst gjennomføre straffen, mens helsemyndighetene skal sikre fengsledes helsetjenester på lik linje med resten av landets borgere. Legene får til mye, men forteller også om vanskeligheter. Om en utfordrende jobb der fangene også blir syke av fengslingen i seg selv, særlig av isolasjon. Om å fors $ø$ ke å finne løsninger innenfor et rigid system de ikke kan endre.

Som sosiologistudent var jeg interessert i hva leger gjør når det oppstår motsetninger mellom hensynet til straffen og hensynet til fangenes helse. Sosiologer studerer gjerne slike krysspressposisjoner, der ulike systemer møtes og må håndteres i hverdagen. Jeg intervjuet leger om dilemmaer de sto $i$, og undersøkte tekster fra Legeforeningen og helsemyndighetene som styrer arbeidet deres. Jeg fant mange dilemmaer - men veldig lite om hvordan legene skulle løse dem.
Helsearbeid i fengsel er et vanskelig felt det er liten politisk interesse for. Samtidig er fangebefolkningen spesielt utsatt: både psykisk og fysisk sykdom er mer utbredt enn hos innbyggerne for $\varnothing v r i g$. Og de rekrutteres fra den delen av befolkningen med lavest inntekt og utdanning, og generelt dårligst levekår. Mange har rusproblemer. De kan ikke fritt oppsøke helsevesenet som oss andre. Dårligere helse eller helsetilbud skal likevel ikke være en del av straffen.

Kriminalomsorgen, som fengselsvesenet heter, har ansvar for fangene, men ikke helsetilbudet deres. Mens helsevesenet, som ikke heter helseomsorgen, har sitt blikk på hele befolkningen. Og der vandrer fangene i blindsonen. Når konflikter oppstår mellom fengselets mandat og fangenes helseinteresser, blir det avgjørende hva slags ordninger som lages for å håndtere slike motsetninger, og hvor makten legges. En konflikt i Troms $\varnothing$ fengsel avdekket at vi mangler slike ordninger. Og at fengselshelsetjenesten er en kasteball mellom myndighetene som deler ansvaret for syke fengslede.

Da helsetjenesten i Troms $\varnothing$ fengsel flere ganger opplevde at deres medisinskfaglige råd ble tilsidesatt av fengselsledelsen, varslet de Kriminalomsorgen om at liv og helse sto i fare fordi avgjørelser om syke fanger ble tatt av personer uten medisinskfaglig kompetanse. Fengselslederen utestengte deretter avsenderen for brevet, allmennlegen Kjetil Karlsen, fra fengselet. Knallhard takling av mannen, ikke ballen. En opprivende konflikt fulgte. På kort tid var helseavdelingens stab skiftet ut gjennom tvangspermitteringer, tvangsforflytninger, protestoppsigelser og sykmeldinger.

Konflikten i Troms $\varnothing$ fengsel avslørte sys- temmangler på mange nivåer. Prosedyrene ved uenighet mellom fengselsmyndighet og helsemyndighet er uklare. Slike regler finnes i Europarådets fengselsreglement, sist godkjent av Norge i 2006. Da Karlsen oppdaget dette, startet han sammen med kolleger kampen for å få reglene implementert i Norge. Det handlet også om å få avklart hvem som har ansvaret når uenigheter oppstår, slik som i Troms $\varnothing$. Troms $\varnothing$ saken ble kastet frem og tilbake mellom ulike nivåer hos helse- og justismyndighetene i flere år. Karlsen beskriver det slik: «Hele saksgangen fremstår for meg som et pingpong-spill av ansvarsfraskrivelse og uansvarlighet.»

Gjennom Tromsø-saken ble Justisdepartementet og Helsedepartementet gjort oppmerksom på de europeiske fengselsreglene og hullene i eget system, og de lovet at reglene skulle implementeres. En ny veileder for fengselshelsetjenesten ble laget i raskt tempo og levert til Helsedirektoratet i 2009. Siden ble det stille. Helt til veilederen ble lagt ut på høring med rekordkorte to ukers svarfrist våren 2012. «Vi skulle gjerne svart, men det rakk vi jo ikke,» fortalte en fengselssykepleier meg i høst. Det er synd. Ikke alt er synlig fra toppen av byråkratiet. Avstanden til det daglige og uvanlige arbeidet i fengslene er stor. Det kom likevel flere kritiske uttalelser. I skrivende stund ligger veilederen fortsatt hos direktoratet, mer enn tre år etter at utkastet var ferdig.

Bildet som tegnes av Troms $\varnothing$-konflikten og mine egne undersøkelser viser et helsepolitisk landskap der ingen synes å ville ta ansvaret. I høst uttalte Justisdepartementet til VG at de ikke ville innføre Europarådets fengselsregler likevel, fordi de «ikke er forpliktende». Denne holdningen bryter med det norske selvbildet når det kommer til internasjonale avtaler. Vi ser oss kanskje først og fremst som forbilde og eksportør av menneskerettigheter, og legeetiske dilemmaer i fengsel som et problem hos «de andre»?

Nå vet jeg en del om hvordan leger løser de vanskelige oppgavene de har i fengsel. Hvordan myndighetene vil sikre uavhengigheten deres, ja, det spørsmålet står fortsatt ubesvart. Ingen har hørt noen rope: «Jeg tar'n!»

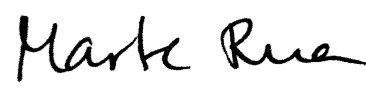

